
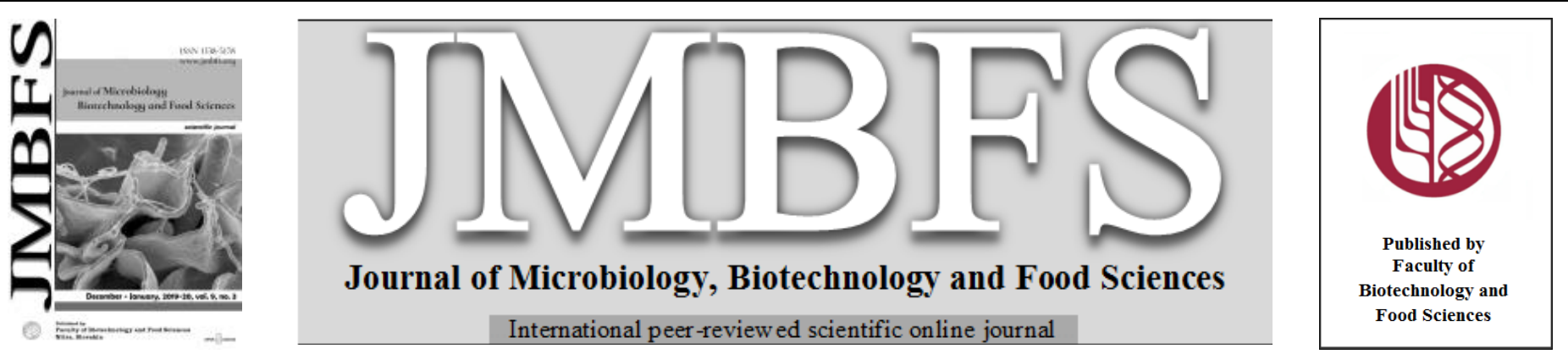

\title{
THE EFFECT OF MILD TEMPERATURE STRESS ON THE OVARIAN ACTIVITY IN COWS
}

\section{Bezdíček, J. ${ }^{1}$, Stádník, $L^{2}{ }^{2}$, Makarevich, A. ${ }^{3}$, Kubovičová, E. ${ }^{3}$, Louda, $F^{4}{ }^{4}$, Hegedüšová, $Z .^{5}$, Holásek, $R .^{5}$}

\author{
Address(es): \\ ${ }^{1}$ Palacký University Olomouc, Department of zoology and laboratory of ornithology, Faculty of Science, 17. listopadu 50, 77146 Olomouc, Czech Republic. \\ ${ }^{2}$ Czech University of Life Sciences Prague, Department of Animal Husbandry, Faculty of Agrobiology, Food and Natural Resources, Kamýcká 129,16500 Praha 6 \\ Suchdol, Czech Republic. \\ ${ }^{3}$ Research Institute for Animal Production Nitra, National Agricultural and Food Centre (NPPC), Hlohovecka 2, 95141 Lužianky-near-Nitra, Slovak Republic. \\ ${ }^{4}$ Research Institute for Cattle Breeding Rapotin, Ltd., Department of feed, nutrition, breeding and reproduction, Vyzkumniku 267, 78813 Vikyrovice, Czech Republic. \\ ${ }^{5}$ Taura ET Ltd.
}

*Corresponding author: jiri.bezdicek@upol.cz

doi: 10.15414/jmbfs.2019/20.9.3.639-642

ARTICLE INFO

Received 30. 5. 2019

Revised 5. 9. 2019

Accepted 5. 9. 2019

Published 1. 12. 2019

Regular article

OPEN OACCESS $_{\text {AC }}$

\section{ABSTRACT}

The aim of this study was to evaluate the effect of mild temperature stress on ovarian activity (corpus luteum count; transferable embryos; morulae and blastocysts) in cows. The evaluation included 54 Holstein cows superovulated and flushed at one farm in the Czech Republic in three different temperature periods in flushing day (mild hot season THI $=75.66$; season with optimal temperature $\mathrm{THI}=68.85$; season with lower temperature THI $=45.56$ ). The data were analysed using the PROC GLM of Statistica ${ }^{\circledR}$. The statistical model included the effect of season and other factors (age; condition; breeding value) on the studied reproduction traits. The results showed significantly higher ovarian activity in the cooler period of the year than in periods of mild temperature stress. There was also a non-significantly better reproduction result in younger animals under optimal condition.

Keywords: temperature stress; corpus luteum; embryo transfer

\section{INTRODUCTION}

In cattle breeding, there is generally maximum effort exerted to avoid stress in the animals. One of important stress factors is a temperature proven to have a negative effect on a number of physiological traits. For this reason, concerted effort is made to ensure cooling for the animals in the hot summer months, for example using cattle showers and shades. The reduction in the body temperature using cattle showers was reported by Legrand et al. (2011) and the importance of shade and its relationship to reducing temperature stress was described by Schütz et al. (2011).

The influence of temperature stress has been demonstrated for a number of physiological functions, e.g. reproduction (Al-Katanani et al., 1999; De Rensis et al., 2002; Schüller et al., 2014), milk production (André et al., 2011; Bernabucci et al., 2002), milk components (Bernabucci et al., 2014) and in different animal species (Olexikova et al., 2007, 2008; 2010; 2013; Makarevich et al., 2007). In the area of reproduction, temperature stress was described at different levels, for example from the point of view gametogenesis (Nichi et al., 2006), early embryo mortality (Ryan et al., 1993), service period (Oseni et al., 2004; Ray et al., 1992) etc.

Temperature stress was also investigated in the area of gametogenesis, in both male and female animals. In bulls, the influence of temperature stress on the quality of the ejaculate was studied. This relationship has also been demonstrated, for example by Mathevon et al. (1998), Nichi et al. (2006) and other authors.

In female animals temperature stress has been the subject of number of studies. Al-Katanani et al. 2002 found a lower proportion of embryos developed to blastocysts during the warm season compared with the cool season. Similar findings are reported by Rocha et al. (1998). These authors found higher production of normal oocytes during the cool season $(75.9 \%)$ than in the hot season $(41.0 \%)$. They also determined a higher percentage of oocytes developing to the 8-cell and morula stage (65.4 and $46.6 \%)$ than in the hot season (21.2 and $6.0 \%$ ). Similar conclusions were drawn in our previous study Bezdíček et al. (2015) on embryo transfer. We found a significantly lower number of obtained embryos in the hot months of the year than the cold period and also a lower proportion of transferable embryos in the hot months. Similar findings were reported by Ferreira et al. (2011), Putney et al. (1988), Ryan et al. (1993) and other authors.
The effect of temperature stress was also confirmed by comparing the development of heat-stressed and non-heat-stressed bovine ova. Edwards et al. (2009) found a reduced development of the blastocyst, when morulae were cultured under heat-stress $\left(41.0{ }^{\circ} \mathrm{C}\right)$ in comparison with non-heat-stressed morulae $\left(38.5^{\circ} \mathrm{C}\right)$. These conclusions were reported by other authors too (Sakatanet et al., 2015; Edwards and Hansen, 1997). Research in this area also focuses on efforts to ameliorate the situation and improve reproduction in heatstressed cows, for example, by vitamin A (Lawrence et al., 2004) and not only in cows, during oocyte maturation. Lawrence et al. (2004) reported that heatstressed oocytes (at $41.0^{\circ} \mathrm{C}$ ) with $5 \mu \mathrm{M}$ retinol showed no increase in activation of parthenogenesis. The authors concluded that retinol may protect oocytes from the heat stress (Lawrence et al., 2004).

From the viewpoint of the progesterone production in heat-stressed cows, the results of many studies are often contradictory (Rensis and Scaramuzz, 2003). These authors showed some studies that found a decrease in progesterone level in the heat-stress period (Howell et al., 1994; Ronchi et al., 2001), and others that showed an increased or unchanged concentration of progesterone. Some studies show that the delayed effect of heat stress is also an important factor (Roth et al. 2001a, b).

In tropical and subtropical areas it is important to take into consideration temperature stress. The upper critical temperatures for Holstein cattle in the subtropical climate is $25-26{ }^{\circ} \mathrm{C}$ (Berman et al., 1985). However, temperature stress also refers to other factors, such as humidity, low airflow and direct sunlight (rev. by Scholtz et al., 2013). Therefore, temperature stress is often defined as temperature humidity index (THI), which includes air temperature and relative humidity. Different models for the calculation of temperature stress were reviewed by Dash et al. (2016). Armstrong (1994) categorized the level of THI into five classes: no stress (THI <72), mild stress $(\mathrm{THI}=72-78)$, moderate stress $(\mathrm{THI}=79-88)$, severe stress $(\mathrm{THI}=89-98)$ and danger stress $(\mathrm{THI}>98)$.

Temperature stress is a significant factor for reproduction and production traits in livestock. Concerning reproduction, the effect of temperature stress was proved not only in terms of animal husbandry characteristics (service-period, NR rate and others), but also in terms of gametogenesis (males and females) and subsequent embryo development. The aim of this study was to evaluate reproduction in cows (embryo donors) at the beginning of temperature stress (end of spring and early summer). The evaluation was performed by sonographic 
examination of the ovaries after superovulation treatments (corpus luteum count) and subsequent flushing of embryos.

\section{MATERIAL AND METHODS}

The samples were collected from 54 Holstein cows, superovulated at the farm located in the lowlands of the Czech Republic during one year. The average milk production for the $1^{\text {st }}$ lactation at the time of the experiment was as follows: 7843 $\mathrm{kg}$ of milk; $4.01 \%$ of fat; $315 \mathrm{~kg}$ of fat; $3.30 \%$ of protein; $259 \mathrm{~kg}$ of protein. Oestrus of embryo donors was synchronized by prostaglandin F2 $\alpha$ analogue OESTROPHAN (Bioveta a.s., Ivanovice na Hane, Czech Republic). Superovulation was performed by injection of porcine pituitary gonadotropin (Pluset ${ }^{\circledR}$ - FSHp-LHp, Laboratorios Callier, Barcelona, Spain) twice daily for 5 days, at 08:00 and 20:00 h, given in decreasing doses starting with doses of 150 IU of follicle stimulating hormone (FSH) +150 IU luteal hormone ( $\mathrm{LH})$ in the morning on days 11 to $50 \mathrm{IU}$ FSH+50 IU LH in the evening on day 15 of the oestrous cycle. Luteolysis was induced on day 13 by the injection of OESTROPHAN. Insemination was carried out four times with frozen-thawed semen at $12 \mathrm{~h}$ intervals starting at $12 \mathrm{~h}$ after detection of the standing oestrous. Embryo recovery was performed by flushing out the uterine horns on the day 7 after the first insemination. Uterine flushing was done with a complete flush solution (Bioniche, Belleville, Ontario, Canada) using a silicone two-way Foley catheter (Minitüb GmbH, Tiefenbach, Germany). Flushed ova and embryos were transferred to the holding medium (phosphate-buffered solution with $20 \%$ of foetal calf serum - FCS, Gibco BRL, USA). The embryos were evaluated as transferable or non-transferable (degenerated and unfertilized) according to their stage of development using a stereomicroscope. Number of corpus luteum (CL) on both ovaries was determined by a Tringa Linear sonograph (Canmedical, Canada).
Data were analysed using the PROC GLM of Statistica ${ }^{\circledR}$. The effects of season and other factors were estimated from the model as follows:

$\mathrm{Y}_{\mathrm{ijkl}}=\mu+$ Season $_{\mathrm{i}}+\mathrm{Age}_{\mathrm{j}}+\mathrm{BV}_{\mathrm{k}}+$ Condition $_{\mathrm{l}}+\mathrm{e}_{\mathrm{ijk}}$

where :

$\mathrm{Y}_{\mathrm{ijk} \mathrm{l}}=$ corrected value $($ dependent variable $)=$ corpus luteum; transferable embryos; morulae; blastocysts count;

$\mu=$ mean value

Season $_{\mathrm{i}}=$ mild hot temperature $(\mathrm{THI}$ in flushing days $=75.66)$; optimal temperature $(\mathrm{THI}$ in flushing days $=65.85)$; lower temperature $(\mathrm{THI}$ in flushing days $=45.56$

$\operatorname{Age}_{\mathrm{j}}=$ age $(1=$ to 30 months; $2=31-45$ months; $3=$ above 46 months $)$

$\mathrm{BV}_{\mathrm{k}}=$ breeding value $(1=$ to $100 ; 2=101-600 ; 3=$ above 601$)$

Condition $=$ body condition of animal $(1=$ optimal condition $=2.5-3.5$ points; 2 $=$ inappropriate condition $=$ under 2.5 ; above 3.5 points)

$\mathrm{e}_{\mathrm{ijkl}}=$ residual error.

Differences between the estimated variables were tested at the level of significance $P<0.05(\mathrm{a} ; \mathrm{b})$. Breeding values of milk production were based on the actual results from January 2015

In this study, the temperature and humidity relationship was calculated according to the following equation:

Temperature-humidity index $(\mathrm{THI})=0.8 \times$ ambient temperature $+[(\%$ relative humidity $\div 100) \times($ ambient temperature -14.4$)]+46.4$ (Buffington et al., 1981)

Maximal day temperature and day humidity were obtained from the Czech Hydro meteorological Institute in Prague. The THI index was calculated as the average of four days (day of flushing of embryos and the three preceding days). In a period of mild temperature stress, the maximum THI was 79.89 (Table 1).

Table 1 Weather conditions in days of embryo flushing.

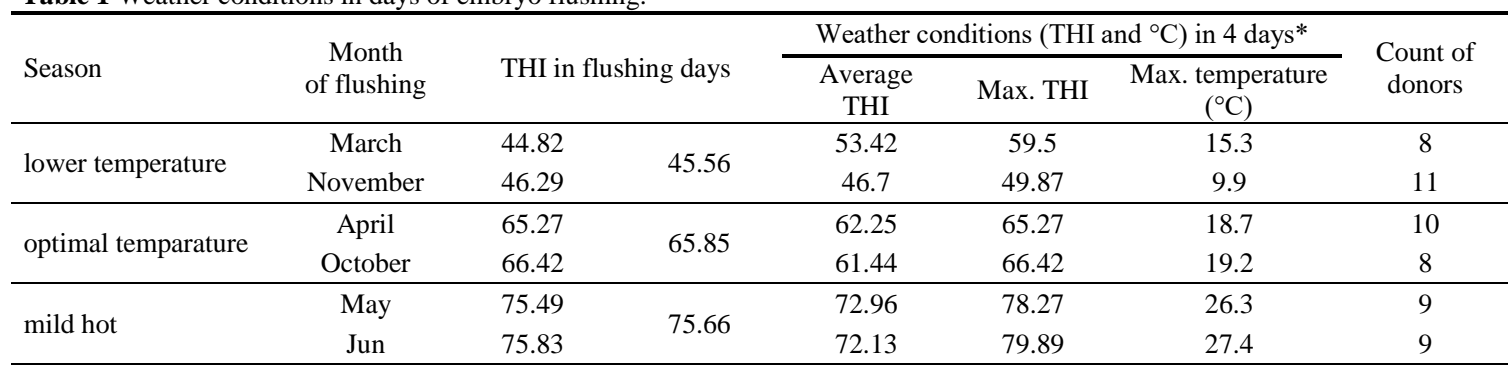

* Weather conditions in 4 days $=$ flushing day and three preceding days

\section{RESUltS AND DISCUSSION}

Test of homogeneity (Cochran-Hartley-Bartlett test) and residual plots (Figure 1) were the first step in the statistical analysis. These tests indicate the suitability of the following GLM analyses.

The influence of different temperature periods of the year (mild hot, optimal, optimal lower) was studied in superovulated cows in terms of number of corpus luteum and number of transferable embryos (morulae and blastocysts). The results showed a lower number of corpus luteum in the mild warm period than in the optimal or optimal lower ambient temperature $(6.05$ vs. $8.15 ; 8.19)$, but the differences were insignificant (table 2). A similar trend was found for transferable embryos $(1.94 ; 2.41 ; 3.73)$ and morulae count $(1.45$ vs. $2.96 ; 3.17)$ At this comparison, the differences between mild warm and optimal lower were significant. The tendency to better ovarian response in cooler periods is also evident from the graphic representation of number of corpus luteum, transferable embryos and the number of morulae (Figures 2, 3 and 4). For the effect "age at flushing" greater numbers of corpus luteum and transferable embryos were found in younger animals (to 30 months), compared to the group of 31 - 45 or over 46 months (corpus luteum: 8.38 vs. $7.37,6.63$, transferable embryos: $2.59,3.26$, 2.23 , morulae: $2.24,3.00,2.35$ ). The effect of "animal condition" was more prominent in the animals with an optimal condition than in animals tending to over- or underweight (corpus luteum: 7.63 vs. 7.29; transferable embryos: 3.18 ; 2.20; morulae 3.04 vs. 2.02) but the differences were not significant. For the factor "breeding value" we found slightly poorer (insignificant) results in animals with higher breeding value $(\mathrm{BV}>600)$. The difference was manifested mainly in corpus luteum count (lower breeding value $=9.07$; high breeding value $=5.64$ ), but this was not significant. Table 2 shows the numbers of blastocysts, but in this case there were fewer donor cows and, therefore, this is only supplementary information to the values of transferable embryos (transferable embryos $=$ morulae + blastocysts).

Table 3 presents the statistics significance of various factors included in the model. Season appears to be the most important factor (according to the F- ratio)

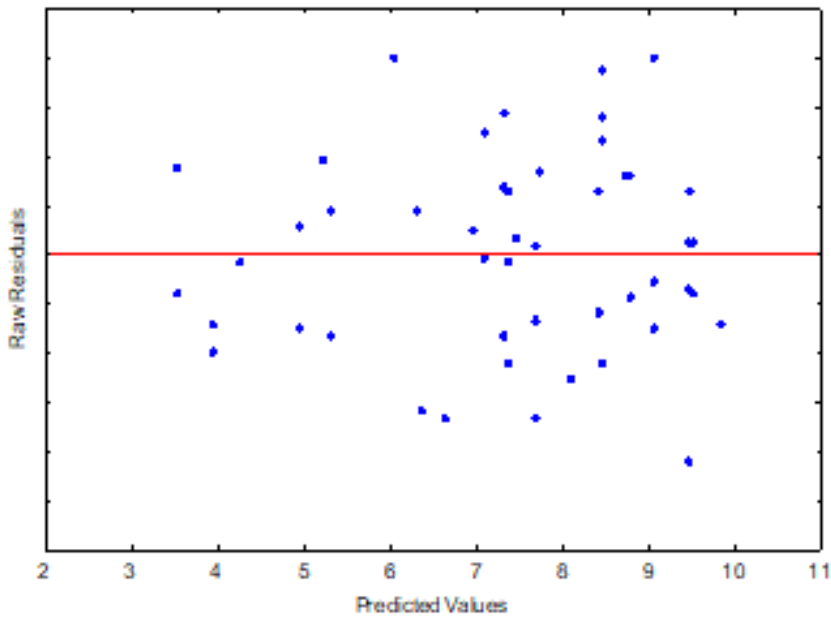

Figure 1 Residual plots: count of corpus luteum 
Table 2 Influence of different factors on ovarian activity in superovulated holstein cows

\begin{tabular}{|c|c|c|c|c|c|c|c|c|c|}
\hline & & \multirow{2}{*}{$\begin{array}{l}\text { Count } \\
\text { curpus } \\
\text { luteum } \\
\text { (LSM) }\end{array}$} & \multirow[b]{2}{*}{$\begin{array}{l}\text { Cows } \\
(\mathrm{N})\end{array}$} & \multirow{2}{*}{$\begin{array}{l}\text { Count of } \\
\text { transferable } \\
\text { Embryos } \\
\text { (LSM) }\end{array}$} & \multirow[b]{2}{*}{$\begin{array}{l}\text { Cows } \\
(\mathrm{N})\end{array}$} & \multicolumn{4}{|c|}{ Transferable Embryos } \\
\hline & & & & & & $\begin{array}{l}\text { Count of } \\
\text { Morulae (LSM) }\end{array}$ & $\begin{array}{l}\text { Cows } \\
(\mathrm{N})\end{array}$ & $\begin{array}{l}\text { Count of } \\
\text { Blastocysts } \\
(\text { LSM) }\end{array}$ & $\begin{array}{l}\text { Cows } \\
(\mathrm{N})\end{array}$ \\
\hline \multirow{3}{*}{ Season } & $\begin{array}{l}\text { mild } \\
(\mathrm{THI}=75.66)^{*}\end{array}$ & $6.05 \pm 1.0353$ & 17 & $1.94 \pm 0.5922^{\mathrm{a}}$ & 17 & $1.45 \pm 0.5134^{\mathrm{a}}$ & 13 & $3.66 \pm 0.6339$ & 3 \\
\hline & $\begin{array}{l}\text { optimal temperature } \\
(\mathrm{THI}=65.85)^{*}\end{array}$ & $8.15 \pm 1.0961$ & 18 & $2.41 \pm 0.4134$ & 18 & $2.96 \pm 0.5255$ & 13 & $1.64 \pm 0.6002$ & 4 \\
\hline & $\begin{array}{l}\text { lower temperature } \\
(\mathrm{THI}=45.56)^{*}\end{array}$ & $8.19 \pm 1.0297$ & 18 & $3.73 \pm 0.6105^{\mathrm{a}}$ & 16 & $3.17 \pm 0.4716^{\mathrm{a}}$ & 15 & $1.61 \pm 0.44275$ & 8 \\
\hline \multirow{3}{*}{ Age } & to 30 months & $8.38 \pm 1.3380$ & 13 & $2.59 \pm 0.7911$ & 12 & $2.24 \pm 0.6397$ & 11 & $2.04 \pm 1.0868$ & 2 \\
\hline & $31-45$ months & $7.37 \pm 0.9408$ & 20 & $3.26 \pm 0.5517$ & 19 & $3.00 \pm 0.4949$ & 15 & $2.78 \pm 0.4311$ & 9 \\
\hline & above 46 & $6.63 \pm 1.0023$ & 20 & $2.23 \pm 0.5732$ & 20 & $2.35 \pm 0.4944$ & 15 & $2.10 \pm 0.6204$ & 4 \\
\hline \multirow{3}{*}{$\begin{array}{l}\text { Breeding } \\
\text { value }\end{array}$} & to 100 & $9.07 \pm 1.20$ & 15 & $3.65 \pm 0.6894$ & 15 & $2.68 \pm 0.5620$ & 13 & $2.14 \pm 0.5726$ & 7 \\
\hline & $101-600$ & $7.67 \pm 0.9971$ & 22 & $2.26 \pm 0.5985$ & 20 & $2.32 \pm 0.5073$ & 16 & $1.83 \pm 0.7910$ & 5 \\
\hline & above 600 & $5.64 \pm 1.1078$ & 16 & $2.17 \pm 0.6340$ & 16 & $2.58 \pm 0.5846$ & 12 & $2.94 \pm 0.8225$ & 3 \\
\hline \multirow[b]{2}{*}{ Condition } & optimal condition & $7.63 \pm 0.7797$ & 32 & $3.18 \pm 0.4530$ & 31 & $3.04 \pm 0.3656$ & 26 & $2.06 \pm 0.3723$ & 9 \\
\hline & $\begin{array}{l}\text { inappropriate } \\
\text { condition } \\
\end{array}$ & $7.29 \pm 0.9610$ & 21 & $2.20 \pm 0.5647$ & 20 & $2.02 \pm 0.4788$ & 15 & $2.56 \pm 0.4800$ & 6 \\
\hline Adjusted $\mathrm{R}^{2}$ & & 0.0392 & & 0.1057 & & 0.1048 & & 0.2652 & \\
\hline
\end{tabular}

Table 3 Significance of various factors included in the model

\begin{tabular}{|c|c|c|c|c|c|c|c|c|c|c|c|c|}
\hline & \multicolumn{3}{|c|}{ Corpus Luteum } & \multicolumn{3}{|c|}{ Transferable embryos } & \multicolumn{3}{|c|}{ Morulae } & \multicolumn{3}{|c|}{ Blastocysts } \\
\hline & SS & $\mathrm{F}$ & $\mathrm{p}$ & SS & $\mathrm{F}$ & $\mathrm{p}$ & SS & $\mathrm{F}$ & $\mathrm{p}$ & SS & $\mathrm{F}$ & $\mathrm{p}$ \\
\hline Season & 48.35 & 1.48 & 0.2536 & 24.96 & 2.56 & 0.1192 & 22.1 & 3.96 & 0.0419 & 7.57 & 4.75 & 0.0617 \\
\hline Age & 16.11 & 0.4715 & 0.6271 & 9.96 & 0.8921 & 0.4172 & 4.7 & 0.6477 & 0.5297 & 1.26 & 0.7100 & 0.5239 \\
\hline $\begin{array}{l}\text { Breeding } \\
\text { Value }\end{array}$ & 66.36 & 1.20 & 0.1552 & 17.77 & 1.13 & 0.2154 & 0.86 & 0.1362 & 0.8731 & 0.54 & 0.3068 & 0.7452 \\
\hline Condition & 1.21 & 0.0706 & 0.7917 & 9.79 & 1.30 & 0.1925 & 8.55 & 2.91 & 0.1086 & 0.73 & 0.8160 & 0.3964 \\
\hline
\end{tabular}

$\mathbf{2 a}$

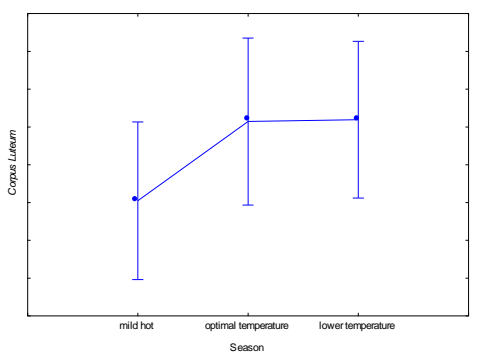

$2 \mathrm{~b}$

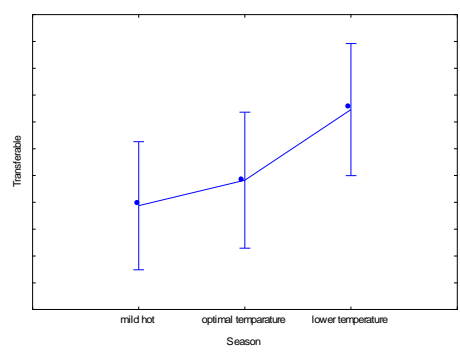

2c

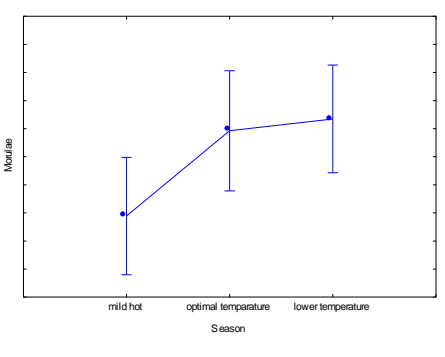

Figure 2 Ovarian activity (2a corpus luteum; $2 \mathrm{~b}$ transferable embryos; $2 \mathrm{c}$ morulae as count) in different seasons of the year

Al-Katanani et al. (2002) investigated heat stress in Holstein cows using in vitro methodology. The authors found that the percentage of embryos that developed into blastocysts (8 days after fertilization) was lower in the warm season than in the cold season. A comparison of results in the season with heat stress and winter season showed a lower number of collected oocytes (19.3 vs. 25.1), lower percent of blastocysts at d 8 (11.4 vs. 29.9 out of total oocytes) and lower total cell number (68.8 vs. 82.4)

Rocha et al. (1998) also found lower oocyte production in the warm season of a year. In superovulated cows, the authors described a significantly lower percentage of normal oocytes (24.4 vs. 80.0) and lower percentage of fertilized oocytes developing to the 8-cell, morula and blastocyst stage during the hot season, than in the cool season.

Putney et al. (1988) found an effect of heat stress on the proportion of degenerate embryos. In stressed Holstein heifers there was a lower percentage of normal embryos than in thermoneutral animals (20.7 vs. $51.5 \%)$. The authors concluded that stressed Holstein heifers had a higher incidence of impaired (abnormal and retarded) embryos with degenerate, nonviable blastomers than heifers in a thermoneutral climate. Wilson et al. (1998) also reported the effect of heat-stress on ovarian activity as smaller follicle size and decrease in serum estradiol concentrations in heat-stressed heifers. They concluded that heat stress inhibited growth and function of the dominant follicle. Similar findings are described by López-Gatius et al. (2010), who found unimportant relationship between corpus luteum and response of embryos to stress factors in the early foetal period. Increasing heat stress $(\mathrm{THI} \geq 74)$ is also connected with decreased serum progesterone concentration $(<1 \mathrm{ng} / \mathrm{ml})$ on the day of oestrus (Schüller et al., 2017). Authors also found, that increasing temperature stress (for each THI point) is associated with decreased follicular size by $0.1 \mathrm{~mm}$.

\section{CONCLUSION}

These results show the significant effect of the mild hot season on cattle reproduction. Ovarian activity in superovulated cows, represented by the number of corpus luteum, transferable embryos and morulae count, was significantly higher in the cooler period of the year than in periods of moderate temperature stress. Although better results were found in younger animals in optimum condition, the differences between groups were insignificant. Conclusions show, that also mild temperature stress can bring a slightly worse ovarian response in superovulated cows

Acknowledgement: This work was supported by "S" grant of MSMT CR and the research project NAZV QI91A061.

\section{REFERENCES}

Al-Katanani, Y. M., Webb, D. W. \& Hansen P. J. (1999). Factors affecting seasonal variation in 90-day non-return rate to first service in lactating Holstein cows in a hot climate. Journal of Dairy Science, 82(12), 2611-2616. doi 10.3168/jds.S0022-0302(99)75516-5.

Al-Katanani, Y. M., Paula-Lopes, F. F. \& Hansen, P. J. (2002). Effect of season and exposure.to heat stress on oocyte competence in Holstein cows. Journal of Dairy Science, $85, \quad 390-396 . \quad$ doi: https://doi.org/10.3168/jds.S00220302(02)74086-1

André, G., Engel, B., Berentsen, P. B. M., Vellinga, Th. V. \& Oude Lansink, A. G. J. M. (2011). Quantifying the effect of heat stress on daily milk yield and 
monitoring dynamic changes using an adaptive dynamic model. Journal of Dairy Science, 94(9), 4502-4513. doi: https://doi.org/10.3168/jds.2010-4139

Armstrong, D.V. (1994). Heat stress interactions with shade and cooling. Journal of Dairy Science, 77(7), 2044-2050. doi:_ https://doi.org/10.3168/jds.S00220302(94)77149-6

Berman, A. (1985). Upper critical temperatures and forced ventilation effects for high yielding dairy cows in a subtropical climate. Journal of Dairy Science, 68(6), 1488-1495. doi: https://doi.org/10.3168/jds.S0022-0302(85)80987-5 Bernabucci, U., Lacetera, N., Ronchi, B. \& Nardone, A. (2002). Effects of the hot season on milk protein fractions in Holstein cows. Animal Research, 51, 25-33. doi: https://doi.org/10.1051/animres:2002006

Bernabucci, U., Basiricò, L., Morera, P., Dipasquale, D., Vitali, A., Picciol Cappelli, F. \& Calamari, L. (2014). Effect of summer season on milk protein fractions in Holstein cows. Journal of Dairy Science, 98(3), 1815-1827. doi: 10.3168/jds.2014-8788

Bezdíček, J., Makarevich, A., Stádník, L., Kubovičová, E., Louda, F., Hegedüšová, Z., Holásek, R., Ducháček, J. \& Stupka, R. (2015). Analysis of factors affecting the quantity and quality of embryo production in superovulated cows. Züchtungskunde, 87(4), 249-264.

Buffington, D. E., Collazo-Arocho, A., Canton, G. H., Pitt, D., Thatcher, W. W. \& Collier. R. J. (1981). Black globe-humidity index (BGHI) as comfort equation for dairy cows. American Society of Agricultural and Biological Engineers. 24(3), 711-714.

Dash, S., Chakravarty, A. K., Singh, A., Upadhyay, A., Singh, M. \& Yousuf, S (2016). Effect of heat stress on reproductive performances of dairy cattle and buffaloes. Veterinary World. 9(3), 235-244. doi: 10.14202/vetworld.2016.235244

De Rensisi, F., Marconi, P., Capelli, T., Gatti, F., Facciolongo, F., Franzini, S. \& Scaramuzzi, R. J. (2002). Fertility in postpartum dairy cows in winter or summe following estrus synchronization and fixed time AI after the induction of an LH surge with GnRH or hCG. Theriogenology, 58(9), 1675-1687. https://doi.org/10.1016/S0093-691X(02)01075-0.

De Rensis, F. \& Scaramuzzi, R. J. (2003). Heat stress and seasonal effects on reproduction in the dairy cow-a review. Theriogenology, 60(6), 1139-1151. https://doi.org/10.1016/S0093-691X(03)00126-2.

Edwards, J. L., Bogart, A. N., Rispoli, L. A., Saxton, A.M. \& Schrick, F. N (2009). Developmental competence of bovine embryos from heat-stressed ova Journal of Dairy Science, 92(2), 563-570. https://doi: https://doi.org/10.3168/jds.2008-1495.

Edwards, J. L., Hansen, P. J. (1997). Differential responses of bovine oocytes and preimplantation embryos to heat shock. Molecular Reproduction and Development, 46(2), 138-145. https://doi.org/10.1002/(SICI)1098 2795(199702)46:2<138::AID-MRD4>3.0.CO;2-R

Ferreira, R. M., Ayres, H., Chiaratti., M. R., Ferraz, M. L., Araujo, A. B. Rodrigues, C. A., Watanabe, Y. F., Vireque, A. A., Joaquim, J. C., Smith, L. C., Meirelles, F. V. \& Baruselli, P.S. (2011). The low fertility of repeat-breeder cows during summer heat stress is related to a low oocyte competence to develop into blastocysts. Journal of Dairy Science, 94(5), 2383-2392. doi: 10.3168/jds.2010$\underline{3904}$

Guzeloglu, A, Ambrose, J.D., Kassa, T., Diaz, T., Thatcher, M.J., Thatcher, W.W. (2001). Long term follicular dynamics and biochemical characteristics of dominant follicles in dairy cows subjected to acute heat stress. Animal Reproduction Science, 66(1-2), 15-34. https://doi.org/10.1016/S03784320(01)00082-3

Hahn, G. L. (1999). Dynamic responses of cattle to thermal heat load. Journal of Animal Science, 77(2), 10-20. doi: https://doi.org/10.2527/1997.77suppl_210x Howell, J. L., Fuquay, J. W. \& Smith, A. E. (1994). Corpus luteum growth and function in lactating Holstein cows during spring and summer. Journal of Dairy Science; 77(3), 735-739. https://doi.org/10.3168/jds.S0022-0302(94)77007-7. Lawrence, J. L., Payton, R.R., Godkin, J.D., Saxton, A.M., Schrick, F.N., Edwards, J.L. (2004). Retinol Improves Development of Bovine Oocytes Compromised by Heat Stress During Maturation. Journal of Dairy Science, 87(8), 2449-2454. doi: https://doi.org/10.3168/jds.S0022-0302(04)73368-8.

Legrand, A., Schütz, K. E. \& Tucker, C. B. (2011). Using water to cool cattle: Behavioural and physiological changes associated with voluntary use of cow showers, Journal of Dairy Science, 94(7), 3376-3386. doi: https://doi.org/10.3168/jds.2010-3901.

López-Gatius, F., García-Ispierto, I. \& Hunter, R. H. (2010). Factors affecting spontaneous reduction of corpora lutea and twin embryos during the late embryonic/early fetal period in multiple-ovulating dairy cows. Theriogenology, 73(3), 293-299. doi: 10.1016/j.theriogenology.2009.09.012

Makarevich, A. V., Olexiková, L., Chrenek, P., Kubovičová, E., Freharová, K. \& Pivko J. (2007). The effect of hyperthermia in vitro on vitality of rabbit preimplantation embryo. Physiological Research, 56(6), 789-796.

Mathevon, M., Buhr, M. M. \& Dekkers, J. C. M. (1998). Environmental, management, and genetic factors affecting semen production in Holstein bulls Journal of Dairy Science, 81(12), 3321-3330. https://doi.org/10.3168/jds.S00220302(98)75898-9.

Nichi, M., Bols, P. E. J., Zuge, R. M., Barnabe, V. H., Goovaerst, I. G. F. Barnabe, R. C. \& Cortada C. N. M. (2006). Seasonal variation in semen quality in Bos indicus and Bos taurus bulls raised under tropical conditions Theriogenology, 66(4), 822-828. doi: 10.1016/i.theriogenology.2006.01.056.

Olexikova, L., Makarevič, A. V., Chrenek, P., Kubovicova, E. \& Pivko J. (2007) Development of rabbit preimplantation embryos under thermal stress in vitro. Slovak Journal of Animal Science, 40(2), 63-65.

Olexikova, L., Makarevich, A. V., Kubovičová, E. \& Pivko, J. (2008). The effect of antiserum to heat-shock proteins 70 (Hsp 70) on the in vitro development of porcine embryos exposed to hyperthermia. Slovak Journal of Animal Science, 41(3), 105-108.

Olexiková, L., Makarevich, A. V., Pivko, J. \& Chrenek, P. (2013). Ultrastructure of rabbit embryos exposed to hyperthermia and anti-Hsp70. Anatomia Histologia Embryologia, 42(4), 285-291. doi: org/10.1111/ahe.12014

Olexiková, L., Makarevich, A. V., Pivko, J. \& Chrenek, P. (2010). Antibody to Hsp70 Alters Response of Rabbit Preimplantation Embryos to Hyperthermia in vitro. Animal Reproduction Science, 119(1-2), 130-136. doi: .org/10.1016/j.anireprosci.2009.12.008.

Oseni, S., Mistzal, I., Tsuruta, S. \& Rekaya, R. (2004). Genetic components of days open under heat stress. Journal of Dairy Science, 87(9), 3022-3028. https://doi.org/10.3168/jds.S0022-0302(04)73434-7.

Putney, D. J., Drost, M. \& Thatcher, W. W. (1988). Embryonic development in superovulated dairy cattle exposed to elevated ambient temperatures between Days 1 to 7 post insemination. Theriogenology, 30(2), 195-209.

Ray, D. E., Jassim, A. H., Armstrong, D. V., Wiersma, F. \& Schuh, J. D. (1992) Influence of season and microclimate on fertility of dairy cows in a hot-arid environment. International Journal of Biometeorology, 36(3), 141-145.

Rocha, A., Randel, R. D., Broussard, J. R., Lim, J. M., Blair, R. M., Roussel, J. D., Godke, R. A. \& Hansel, W. (1998). High environ-mental temperature and humidity decrease oocyte quality in Bos taurus but not in Bos indicus cows. Theriogenology, 49(3), 657-665.

Ronchi, B., Stradaioli, G., Verini Supplizi, A., Bernabuci, U., Lacetera, N., Accorsi, P.A., et al. (2001). Influence of heat stress or feed restriction on plasma progesterone, oestradiol-17beta, LH, FSH, prolactin and cortisol in Holstein heifers. Livestock Production Science, 68(2-3), 231-241. doi: https://doi.org/10.1016/S0301-6226(00)00232-3

Roth, Z., Meweidan, R., Shaham-Albalancy, A., Braw-Tal, R. \& Wolfenson, D. (2001a). Delayed effect of heat stress on steroid production in medium-size and preovulatory bovine follicles. Reproduction, 121, 745-751.

Roth, Z., Arav, A., Bor, A., Zeron, Y., Braw-Tal, R. \& Wolfenson, D. (2001b). Improvement of quality of oocytes collected in the autumn by enhanced removal of impaired follicles from preovulatory heat-stressed cows. Reproduction, 122:737.

Ryan, D. P., Prichard, J. F., Kopel, E. \& Godke, R. A. (1993). Comparing early embryo mortality in dairy cows during hot and cool seasons of the year Theriogenology, 39(3), 719-737. https://doi.org/10.1016/0093-691X(93)90257-6. Sakatani, M., Yamanaka, K., Balboula, A.Z., Takenouchi, N., Takahashi, M. (2015). Heat stress during in vitro fertilization decreases fertilization success by disrupting anti-polyspermy systems of the oocytes. Molecular Reproduction and Development, 82, 36-47. https://doi.org/10.1002/mrd.22441.

Scholtz, M.M., McManus, C., Leeuw, K. J., Louvandini, H., Seixas, L., de Melo, C. B., Theunissen, A., Neser, F. W. C. (2013). The effect of global warming on beef production in developing countries of the southern hemisphere, Natural Science, 2013, 5(1a), 106-119. doi: 10.4236/ns.2013.51A017.

Schüller, L. K., Burfeind, O. \& Heuwieser, W. (2014). Impact of heat stress on conception rate of dairy cows in the moderate climate considering differen temperature - humidity index thresholds, periods relative to breeding, and heat load indices, Theriogenology, 81(8), 1050-1057. doi 10.1016/j.theriogenology.2014.01.029

Schüller, L. K., Michaelis, I. \& Heuwieser, W. (2017). Impact of heat stress on estrus expression and follicle size in estrus under field conditions in dairy cows Theriogenology, 102, 48-53. doi: 10.1016/j.theriogenology.2017.07.004

StatSoft, Inc. (2013). STATISTICA (data analysis software system), version 12 www.statsoft.com.

Wilson, S. J., Kirby, C. J., Koenigsfeld, A. T., Keisler, D. H. \& Lucy, M. C. (1998). Effects of controlled heat stress on ovarian function of dairy cattle. 2 Heifers. Journal of Dairy Science, 81(8), 2132-2138. doi: 10.3168/jds.S0022$\underline{0302(98) 75789-3}$ 